\title{
PERANAN PENGHULU TERHADAP HAK ULAYAT DI MINANGKABAU*
}

\author{
Eviandi Ibrahim \\ STIH Putri Maharaja Payakumbu \\ J1. Inai Belakang SPBU/Pengadilan Agama Koto Nan IV Kota Payakumbuh \\ e-mail: eviandi.ibrahim01@gmail.com
}

\begin{abstract}
Sumatra in general and Banuhampu District in particular the existence of customary rights is decreasing day by day both in terms of quantity and quality. The reduced existence of customary rights is because the customary rights have been traded by the legal community, in the case that Minangkabau customary law prohibits the sale and purchase of customary rights, this is stated in the customary kato "Jua indak eaten by bali, pawning indak eaten sando" means that ulayat rights can not be traded and transferred ownership to parties outside the legal community fellowship. Based on the above, the authors are interested in conducting research with the following problems: How are customary rights in Banuhampu District? What is the role of the leader / Pangatuo of the tribe / clan or the head of the inheritance of the ulayat rights in Banuhampu? What is the solution taken to defend the existence of customary rights in Banuhampu District? This research is juridicalsocial, because the researcher will examine how the application of law, namely customary law, in the development of the existence of customary rights among the Banuhampu community. Based on the discussion that the author puts forward, the following conclusions can be drawn: Whereas Customary Land (Ulayat) Currently its existence in Banuhampum can still be maintained. Even though it's been much less. This can be proven that until now the Legal Alliance in the Customary Law Community, namely Nagari, Tribe, Kaum, are still alive and existent, and each Legal Alliance still has customary rights although both in terms of quantity and quality have decreased. Whereas Ninik mamak / Penghulu / Pangatuo Suku / Kaum is a person who plays a very big role in the midst of his community / association, because ninik mamak has the right and obligation to take care of his children and nephews along with their communal customary rights, and has the obligation to preserve their customary rights. Whereas the customary rights must be maintained, because the ulayat rights are the identity of the association and the ulayat rights are not property rights, therefore the ulayat rights are prohibited from being transferred or sold.
\end{abstract}

Keywords: Role; Penghulu; Hak Ulayat.

\begin{abstract}
Abtrak
Sumatera pada umumnya dan Kecamatan Banuhampu pada khusunya keberadaan hak ulayat semakin hari semakin berkurang baik secara kuantitas dan kualitasnya. Berkurangnya keberadaan hak ulayat itu karena hak ulayat itu sudah diperjual belikan oleh masyakat hukumnya, pada hal hukum adat Minangkabau melarang terjadinya jual beli hak ulayat itu, hal itu tertuang dalam kato adat "Jua indak dimakan bali, gadai indak dimakan sando" artinya hak ulayat itu tidah boleh diperjual belikan dan beralih kepemilikannya kepada pihak diluar persekutuan masyarakat hukum tersebut. Berdasarkan hal diatas penulis tertarik untuk melakukan penelitian dengan permasalahan sebagai berikut: Bagaimana hak ulayat di Kecamatan Banuhampu Saat ini ? Bagaimana peranan penghulu/Pangatuo suku/kaum atau mamak kepala waris terhadap hak ulayat di Banuhampu? Apa jalan keluar yang ditempuh untuk mempertahankan keberadaan hak ulayat itu di Kecamatan Banuhampu? Penelitian ini bersifat Yuridis Sosilogis, karena peneliti akan meneliti bagaimana penerapan hukum, yakni hukum adat dalam perkembangan keberadaan hak ulayat ditengah-tengah masyarakat Banuhampu. Berdasarkan pembahasan yang penulis kemukakan, maka dapat di tarik kesimpulan sebagai berikut: Bahwa Tanah Adat (Ulayat) Saat ini keberadannya di
\end{abstract}

\footnotetext{
* Naskah diterima: 23 September 2020, direvisi: 28 September 2020, disetujui untuk terbit: 30 September 2020 Doi: $10.3376 /$ jch.v6i1.296
} 
Banuhampum masih dapat dipertahankan. Walaupun sudah jauh berkurang. Hal ini dapat dibuktikan bahwa sampai sekarang Persekutuan Hukum dalam Masyarakat Hukum Adat yaitu Nagari, Suku, Kaum, masih tetap hidup dan eksis, dan masing-masing Persekutuan Hukum itu masih mempunyai hak ulayat walaupun baik dari segi kuantitas dan kualitasnya sudah berkurang. Bahwa Ninik mamak/Penghulu/Pangatuo Suku/Kaum adalah orang yang sangat besar peranannya di tengah-tengah kaum/persekutuannya, karena ninik mamak mempunyai hak dan kewajiban untuk mengurus anak dan kemenakannya beserta hak ulayat persekutuannya, dan mempunhai kewajiban untuk melestarikan hak ulayatnya. Bahwa Hak Ulayat harus dipertahankan keberadaannya, karena hak ulayat merupakan identitas dari persekutuan dan hak ulayat bukan hak milik, maka hak ulayat dilarang untuk dialihkan atau dijual.

Keywords: Peranan; Penghulu; Hak Ulayat.

\section{PENDAHULUAN}

Bagi masyarakat Minangkabau tanah ulayat adalah unsur pengikat bagi masyarakat untuk tinggal di suatu wilayah dan merupakan identitas masyarakat yang secara konstitusional dilindungi oleh UUD 1945. Oleh karena itu, sudah merupakan kewajiban setiap orang untuk menjaga aset tersebut agar tidak tergilas oleh perkembangan zaman. Hingga hari ini, diskursus tanah ulayat tidak kunjung selesai. Dalam rangka menarik investor untuk menanamkan investasinya di daerah. (Buan, 2017)

Hak Ulayat merupakan hak masyarakat hukum adat atas segala sumber daya agraria yang ada dalam wilayah kekuasaan masyarakat hukum adat yang bersangkutan. Dengan demikian obyek dari hak ulayat meliputi segala sumber daya agraria (bumi, air dan kekayaan alam yang terkandung di dalamnya). Hak Ulayat lahir bukan karena diciptkan oleh keputusan pejabat tetapi tumbuh dan berkembang (serta juga dapat lenyap) sesuai dengan keberadaan dan perkembangan kehidupan masyarakat hukum adat yang bersangkutan. (Ismail, 2010)
Hak ulayat dan hak-hak yang serupa itu dari masyarakat hukum adat didefinisikan sebagai kewenangan yang menurut hukum adat dipunyai oleh masyarakat hukum adat tertentu atas wilayah tertentu yang merupakan lingkungan hidup para warganya untuk mengambil manfaat dar sumber daya alam termasuk tanah, dalam wilayah tersebut, bagi kelangsungan hidup dan kehidupannya yang timbul dari hubungan secara lahiriyah dan batiniyah turun temurun dan tidak terputus antara masyarakat hukum adat tersebut dengan wilayah yang bersangkutan. Perihal mengenai pengakuan terhadap hak ulayat, memperhatikan hal tersebut $\mathrm{di}$ atas nampak bahwa hukum adat merupakan dasar dari hukum agraria.

Keberadaan tanah Ulayat telah diakui oleh Undang-Undang Pokok Agraria, Pasal 3 menyatakan bahwa pelaksanaan hak ulayat dan hak-hak yang serupa itu dari masyarakat- masyarakat hukum adat sepanjang menurut kenyataannya masih ada harus sedemikian rupa sehingga sesuai dengan kepentingan nasional dan Negara yang berdasarkan atas persatuan bangsa serta tidak boleh bertentangan dengan Undang-Undang dan peraturan yang lebih tinggi. Hal ini dipertegas oleh 
Pasal 5 UUPA yang menyatakan bahwa hukum agraria yang berlaku atas bumi, air dan ruang angkasa ialah hukum adat, sepanjang tidak bertentangan dengan kepentingan nasional dan Negara yang berdasarkan atas persatuan bangsa dengan sosialisme Indonesia serta dengan peraturan-peraturan yang tercantum dalam Undang-Undang ini dan dengan peraturan perundangan lainnya, segala sesuatu dengan mengindahkan unsurunsur yang bersandar pada hukum agama.

Dalam masyarakat hukum adat Minangkabau (Sumatera Barat) dikenal tiga tipe dasar penguasaan atas tanah yaitu; penguasaan secara kelompok atau nagari, secara komunal dan secara perorangan atau pribadi. Penguasaan atas tanah dalam masyarakat Minangkabau diatur dalam peraturan adat yang dipelihara dan ditaati serta dilaksanakan oleh masyarakat secara turn-temurun dengan baik, sehingga apabila timbul pertentangan atau sengketa yang disebabkan oleh tanah, mereka akan menyelesaikannya dengan peraturan adat yang ada dalam masayarakat yang disebut sebagai "Hukum Acara Perdata Adat". Ketentuan. (Amran, 2017)

Pasal 18 B ayat (2) Undang-Undang Dasar 1945, sebagai hasil amandemen, menyatakan bahwa" Negara mengakui dan menghormati kesatuan-kesatuan Masyarakat hukum Adat beserta hak-hak tradisionalnya sepanjang masih hidup dan sesuai dengan perkembangan masyarakat dan prinsip Negara Kesatuan Republik Indonesia, yang diatur dalam undangundang.
Pasal ini merupakan pengakuan resmi yang diberikan Negara dalam konstitusi baik terhadap keberadaan masyarakat hukum adatnya maupun terhadap hak-hak tradisional yang melekat pada masyakat hukum itu. Salah satu hak yang melekat terhadap masyarakat hukum itu adalah Hak Ulayat, walaupun pengakuan itu disertai dengan syarat bahwa hak ulayat itu sepanjang masih hidup. Itu artinya pengakuan itu diberikan Negara terhadap hak ulayat yang masih ada dan diakui oleh persekutuan hukum dalam masyarakat hukum adat tersebut. Pengakuan itu juga memberi arti bahwa Negara tidak akan menghidupkan atau mengadakan hak ulayat baru.

Sementara saat ini di Sumatera pada umumnya dan Kecamatan Banuhampu pada khusunya keberadaan hak ulayat semakin hari semakin berkurang baik secara kuantitas dan kualitasnya. Berkurangnya keberadaan hak ulayat itu karena hak ulayat itu sudah diperjual belikan oleh masyakat hukumnya, pada hal hukum adat Minangkabau melarang terjadinya jual beli hak ulayat itu, hal itu tertuang dalam kato adat "Jua indak dimakan bali, gadai indak dimakan sando" artinya hak ulayat itu tidah boleh diperjual belikan dan beralih kepemilikannya kepada pihak diluar persekutuan masyarakat hukum tersebut.

Berdasarkan hal diatas penulis tertarik untuk melakukan penelitian dengan permasalahan sebagai Berikut: Bagaimana hak ulayat di Kecamatan Banuhampu Saat ini ? Bagaimana peranan penghulu/Pangatuo suku/kaum atau 
mamak kepala waris terhadap hak ulayat di Banuhampu ? Apa jalan keluar yang ditempuh untuk mempertahankan keberadaan hak ulayat itu di Kecamatan Banuhampu?

\section{METODE PENELITIAN}

Penelitian ini bersifat Yuridis Sosilogis, karena peneliti akan meneliti bagaimana penerapan hukum, yakni hukum adat dalam perkembangan keberadaan hak ulayat ditengah-tengah masyarakat Banuhampu. Karena yang menjadi subjek hak ulayat itu adalah persekutuan masyarakat hukum adat yakni Nagari, Suku, dan kaum, maka yang menjadi Populasi dalam penelitian ini adalah seluruh persekutuan hukum tersebut. Namun untuk membantu mempermudah peneliti dalam penelitian ini maka tidak seluruh populasi yang akan diteliti melainkan peneliti akan mengambil bagian dari populasi untuk dijadikan sampel dalam penelitian ini, Pengambilan sampel dalam penelitian ini dilakukan dengan Purposive sample, yakni peneliti dengan subjetifitasnya menentukan sendiri bagian dari populasi yang akan dijadikan sampel. Untuk itu yang dijadikan sampel dalam penelitian ini adalah empat persekutuan hukum dalam bentuk Suku ( Suku Pisang, guci, tanjuang, pili) serta empat persekutuan berbentuk kaum yang diambil masingmasing satu kaum dari suku yang terpilih jadi sampel, serta satu Persekutuan hukum yang berbentuk Nagari. Dengan demikian diharapan sampel yang terpilih bisa menjawab permasalahan yang diajukan dalam penelitian ini.

\section{HASIL DAN PEMBAHASAN}

\section{Hak Ulayat di Banuhampu}

Hak Ulayat adalah hak persekutuan yang dipunyai oleh masyarakathukum adat tertentu atas suatu wilayah tertentu yang merupakan lingkungan hidup para warganya, yang meliputi hak untuk memanfaatkan tanah, hutan, dan air serta isinya sesuai dengan peraturan perundang-undangan. (Yunimar, 2017)

Menurut Van Vollenhoven hak ulayat adalah merupakan suatu rangkaian dari pada wewenang dan kewajibankewajiban suatu masyarakat hukum adat yang berhubungan dengan tanah yang termasuk di lingkungan wilayahnya.

Masyarakat hukum adat memiliki tanah-tanah adat yang diatas nya dibebani hak ulayat, yaitu serangkaian wewenang dan kewajiban suatu masyarakat hukum adat, yang berhubungan dengan tanah yang terletak dalam lingkungan wilayahnya, sebagai pendukung utama hidup dan berkehidupan masyarakat yang bersangkutan sepanjang masa. Disamping itu hak ulayat itu tidak hanya meliputi tanah yang sudah digarap, tetapi juga hutan adat sepanjang digunakan untuk kelangsungan hidup bagi warga masyarakat hukum adat. (Sukirno, 2018)

Hak ulayat mempunyai ciri-ciri tertentu, ciri-ciri tersebut adalah (Dharmayuda, 2009):

a. Hanya persekutuan hukum itu sendiri beserta para warganya yang berhak dengan bebas mempergunakan tanahtanah liar di wilayah kekuasannya. 
Eviandi Ibrahim: Peranan Penghulu Terhadap Hak Ulayat Di Minangkabau

b. Orang luar hanya boleh mempergunakan tanah itu dengan izin penguasa persekutuan tersebut, tanpa persetujuan tersebut dianggap melakukan pelanggaran.

c. Warga persekutuan boleh mengambil manfaat dari wilayah hak ulayat dengan tujuan untuk keperluan keluarganya sendiri, jika dimanfaatkan untuk kepentingan orang lain, maka ia dipandang sebagai orang asing, sehingga harus mendapat izin terlebih dahulu. Sedangkan orang asing hanya diperkenankan mengambil manfaat di wilayah hak ulayat dengan izin kepala adat dengan disertai pembayaran upeti kepada persekutuan adat.

d. Persekutuan hukum bertanggung jawab atas segala hal yang terjadi dalam wilayahnya terutama yang berupa tindakan melawan hukum yang merupakan delik.

e. Hak ulayat tidak dilepaskan, dipindah tangankan, diasingkan untuk selamanya.

f. Hak ulayat meliputi juga tanah yang sudah di garap, Atau dikuasai oleh orang perorangan.

Ada 3 (tiga) jenis tanah ulayat dalam sistem hukum masyarakat adat Minangkabau (Edison; Nasrun DT.Marajo Sungut, 2010 and Andiki et al., 2019):

1. Ulayat Nagari, yaitu tanah hutan diluar kawasan hutan lindung (Cagar Alam) atau hutan negara tidak termasuk kawasan yang telah menjadi ulayat suku atau ulayat kaum;
2. Ulayat Suku, yaitu tanah hutan yang dibuat kawasan hutan negara dan ulayat nagari, belum menjadi ulayat suatu kaum dalam suku tersebut;

3. Ulayat Kaum, yaitu hutan yang sudah lepas dari kekuasaan ulayat nagari, ulayat suku, dan tidak pula termasuk sebagai tanah milik perorangan. Dengan

Jadi tanah ulayat merupakan penguasaan bersama dari suatu kaum/suku, dan Nagari, oleh karena itu sukar sekali unutuk menentukan siapa pemiliknya, karena konsepnya bukan hak milik, tapi hak menguasai secara kolektif.

Dalam pelaksanaannya hak ulayat ini berlaku ke luar dan ke dalam , maksudnya adalah bahwa orang asing yang bukan anggota masyarakat hukum tidak diizinkan memperoleh hak atas tanah ulayat, kecuali kalau dibayar uang adat dan diizinkan oleh kepala adat bersangkukan. (Sayuti Thalib, 1985)

Peruntukan, penggunaan, penguasaan dan pemilikan ditentukan oleh persekutuan masyarakat hukum adat. Peruntukan dan penggunaan tanah ulayat tersebut dilakukan berdasarkan musyawarah dan mufakat untuk kepentingan bersama anggota persekutuan dan kepentingan umum.

Tanah Ulayat dikuasai oleh persekutuan hukum dalam masyarakat hukum adat, yang lahir dari suatu kenyataan dalam untuk kepentingan bersama, dengan mengingat generasi terdahulu (moyang), sekarang dan yang akan datang (anak cucu),sehingga corak 
religius dan magis dari tanah tetap melekat dalam hak persekutuan tersebut.

Baik Nagari, Suku dan Kaum sebagai kelompok masyarakat hukum mempunyai hak menguasai atas tanah ulayat. Berdasarkan hak menguasai dari persekutuan tersebut dalam pelaksanaannya diwakili oleh kepala persekutuan. Nagari akan diawali oleh Wali Nagari. Suku akan diwakili oleh Kepala Suku/penghulu Suku. Kaum diwakili oleh kepala kaum/mamak kepala waris.

Menurut hukum adat dapat diketahui bahwa tanah ulayat itu di dapat berdasarkan warisan (Harta Pusaka). Pewarisan ini merupakan hak turun temurun dan terjadi begitu saja sesuai dengan kodrat alam, yang dalam adat dikatakan " patah tumbuh Hilang Berganti" dan proses peralihan ini sudah tertuang dalam undang-undang adat yang mengatakan:

"Manah yang dipacik panghulu

Manah nan dari panghulu

Dari niniak turun ka mamak

Dari mamak turun ke kamanakan

Sako turun turun temurun

Pusako jawek manjawek"

Ahli waris/warih menurut Hukum adat Minangkabau adalah orang- orang atau kemenakan yang harus menerima harta pusaka peninggalan dari kaum/persekutuan seperti : sawah, ladang, rumah, tanah, bandar buatan, kuburan, Hutan/rimba serta gelar sako/pusako.

Ahli waris ini dapat dibagi atas dua macam:
1. Warih batali darah/ahli waris bertalih darah (Nazab)

2. Warih batali sabab/ahli waris bertali Sebab (Buatan)

Menurut kepercayaan masyarakat Minangkabau, tanah sebagai pusaka (hak ulayat) dari nenek moyang mempunyai sifat religius magis. Sehingga tanah sebagai pusaka harus dipelihara keberadaannya dan ini telah dipatrikan dalam ketentuan adat, bahwa terhadap tanah ulayat ada rumusan " Jua indak dimakan bali " artinya tanah ulayat sebagai pusaka tinggi tidak dapat diperjual belikan.

Masyarakat Minangkabau, memandang tabu perjual belikan tanah ulayat ini, karena dalam anggapan mereka bila terjadi tanah ulayat diperjual belikan maka yang melakukan itu akan mendapatkan kutukan dari arwah nenek moyang mereka dan ada saja bencana yang menimpa mereka, baik berupa kesengsaraan hidup maupun datangnya berbagai penyakit dan bencana lainnya.

Selain itu menurut penelitian di lapangan, tidak dapatnya tanah ulayat diperjual belikan adalah karena :

1. Tanah Ulayat sebagai pusaka, yang turun temurun mempunyai kaitan yang tidak boleh dipisahkan antara generasi terdahulu, sekarang dan yang akan datang. Oleh karena itu suatu kewajiban bagi generasi sekarang untuk menjaga dan memeliharanya guna diwariskan pada generasi yang akan datang. 
2. Merupakan lambg atau simbol dari persekutuan masyarakat adat mereka.

3. Kepemilikan penguasaannya secara kolektif/bersama.

4. Tanah ulayat menunjukan adanya hubungan pertalian darah antara generasi sekarang dengan generasi sebelumnya.

Dengan demikian kalau ada yang menjual tanah ulayat, selain dapat menghilangkan sifat religius magisnya juga akan menurunkan martabat dari persekutuan, bahkan dapat menghilangkan identitas dari masyarakat hukum tersebut. Karena itu sulit untuk menjual tanah ulayat itu.

Dalam kenyataannya menurut penelitian penulis telah banyak sekali tanah ulayat di Banuhampu yang diperjual belikan atau telah beralih kepemilikannya hal ini terjadi karena :

1. Ahli waris merupakan ahli waris tunggal dari tanah ulayat tersebut, hal ini hanya dapat terjadi pada ulayat kaum. Sehingga kalau dia mau menjual tidak perlu persetujuan anggota kaum lainnya, karena memang tidak ada.

2. Semua anggota kaum setuju untuk menjual tanah tersebut karena himpitan ekonomi.

3. Kaumnya Pupuih, Mamak kepala waris tidak mempunyai kemenakan dibawah daguak (kontan), sehingga menganggap kaumnya pupuih atau tdk punya pewaris, sehingga dia berpendapat lebih baik harta dijual dari pada didapat secara percuma oleh orang lain.
4. Pengaruh tanah disertifikatkan, dengan disertifikatkannya tanah ulayat, otomatis nilai ekonominya menjadi tinggi, dia bisa jadi angunan hutang dibank dan mudah untuk diperjual belikan.

5. Pengaruh Letak Kecamatan Banuhampu yang berbatasan langsung dengan kota Bukittinggi, menjadikan harga tanah di Banuhampu apalagi yang ditepi jalan raya menjadi sangat tinggi, sehingga menggiurkan para pemilik tanah untuk menjual tanahnya.

Inilah beberapa hal yang sangat signifikan nenpengaruhi dan menjadi factor utama menyebabkan tanah ulayat makin hari makin habis di Banuhampu.

\section{Peranan Penghulu/Pangatuo Suku/Kaum atau Mamak Kepala Waris Terhadap Hak Ulayat Di Banuhampu.}

Kecamatan Banhampu merupakan masyarakat hukum adat genealogis teritorial yang merupakan kesatuan masyarakat genealogi yang menganut sistem kekerabatan matrilineal. Sistem kekerabatan matrilineal adalah sistem kekerabatan berdasarkan garis keturunan ibu.

Pada Masyarkat Banuhampu terdapat istilah "keutuhan tali perpilin tigo atau tungku tigo sajarng" artinya tiga pimpinan formal dan informal yang menyatu, terpadu kemitraannya dalam melancarkan kebijaksanaan menuju keutuhan bersama. Hal ini bisa dilihat pada kopiah ninik mamak yang mempunyai 3 unsur: (Rifana, 2016) 
1. Pemuka adat, ninik mamak, monti, dubalang, malin, siempu, pemuda dan cerdik pandai, cendikiawan, yang disebut kapak gadai;

2. Alim ulama seperti khadi negeri, imam, bilal, khatib dan siak mesjid, yang berperanan memelihara ketentuan hukum syara' dengan sendi adat bersendikan syara', syara' bersendikan kitabullah; dan

3. Pemegang undang-undang/hukum negara, badan pemerintahan dan lembaga pemerintahan.

Seorang penghulu/ninik mamak berhenti karena melanggar hukum yaitu: (Rinda Rifana, 2016)

a. Tepijak dibenang orang, berarti berzinah, membunuh, syirik dan melawan ibu bapak;

b. Tergantung di galah yang panjang, artinya zalim, tidak adil, merampok, mencuri, penjudi, peminum tuak/arak, pemabuk, meremehkan kehormatan wanita, korupsi dan fitnah;

c. Terkurung di bilik yang dalam, artinya residivis, orang yang dipenjara, kerusakan moral;

d. Tamandi sipincuran nan godang, artinya gila stress atau gangguan jiwa, tapasuntiong bungo nan kombang, tapanjek langsek nan masak.

Aktifitas dari penghulu suku dapat dibagi menjadi 3 (tiga), yaitu: (Rinda Rifana, 2016)

1. Tindakan mengenai urusan tanah berhubung dengan adanya pertalian erat antara tanah dan persekutuan (golongan manusia) yang menguasai tanah itu;

2. Penyelenggaraan hukum sebagai usaha untuk mencegah adanya pelanggaran hukum (preventieve rechtszorg), agar hukum dapat berjalan dengan semestinya; dan

3. Menyelenggarakan hukum sebagai pembetulan hukum, setelah hukum itu dilanggar (repressieve rechtszorg).

Ninik mamak adalah orang yang sangat besar peranannya di tengah-tengah kaum/persekutuannya, karena ninik mamak mempunyai hak dan kewajiban untuk mengurus anak dan kemenakannya beserta hak ulayat persekutuannya, baik ke dalam maupun ke luar.

Harta pusaka/hak ulayat adalah merupakan amanah dari nenek moyang, karena itu harus dijaga dan dipelihara guna diwariskan kepada generasi selanjutnya, sesuai dengan ketentuan adat yang berlaku. Untuk itu ninik mamak harus memelihara dan menjaga tanah ulayat dan berusaha sejauh mungkin tidak menggadaikan apalagi menjual atau mengalihkannya kepada pihak lain.

Menurut penelitian penulis peranan ninik mamak terhadap persekutuan hukumnya suku dan atau kaumnya adalah sebagai berikut:

1. Ninik mamak merupakan kepala waris dari pada harta pusaka, sehingga dia mempunyai wewenang untuk mengurus harta pusaka tersebut untuk dapat dipergunakan oleh anak kemenakannya. 
2. Ninik mamak mempunyai kewajiban untuk mengatur dan membimbing setiap anggota kaum dalam pergaulan hidup sehari-hari dalam masyarakat, serta tata cara berhubungan dengan anggota masyarakat lain yang berada di luar suku atau kaumnya, terutama yang berkaitan dengan tanah ulayat, supaya penggunaan tanah ulayat ini tidak bertentangan dengan kepentingan umum.

3. Memelihara harta pusaka agar jangan sampai harta itu terjual atau beralih pada pihak lain.

4. Menegur atau bila perlu menghukum anggota kaum yang melakukan kesalahan dalam hal penggunaan tanah ulayat bila melanggar kepentingan umum dan hukum adat yang berlaku.

5. Mengatur peruntukan dan penggunaan tanah ulayat.

6. Bertanggung jawab ke luar dan ke dalam pengelolaan tanah ulayat.

Demikian hak, wewenang dan kewajiban dari ninik mamak terhadap persekutuan dan tanah ulayatnya. Ninik mamak sangat menentukan sekali dalam kelangsungan dan kelestarian tanah Ulayat tersebut, agar tanah ulayat terhindar dari hal-hal yang tidak diinginkan oleh masyarakat hukum adat. Dalam kenyataannya peranan Penghulu/Niniak Mamak/Pangatuo Suku/Mamak Kepala Waris, dalam pelestarian tanah ulayat tidak seperti yang digaris oleh hukum adat, karena justru saat ini banyak terjadi peralihan tanah ulayat itu diprakarsai oleh para
Penghulu/Niniak/Pangatuo Suku/mamak kepala waris.walaupun masih ada mereka yang masih menunjukan perannya dalam melestarikan tanah ulayat tersebut tapi jumlahnya kecil.

\section{Jalan Keluar Yang Ditempuh Untuk Mempertahankan Keberadaan Hak Ulayat Itu Di Kecamatan Banuhampu}

Berdasarkan hasil penelitian Penulis ada beberapa hal yang telah dilakukan Pemuka Masyarakat Banuhampu dan Kerapatan Adat Nagari di Banuhampu dalam rangka mempertahankan keberadaan Hak Ulayat/Tanah Ulayat di Banuhampu yakni;

1. Melakukan Revitalisasi Peran dan Fungsi Ninik

Mamak/Penghulu/Pangatuo

Suku/Kaum di Banuhampu agar kembali kepada fungsi semula sesuai ketentuan Hukum Adat Minangkabau.

2. Memperkuat Fungsi Kerapatan Adat Nagari dalam melakukan pengawasan terhadap keberadaan tanah Ulayat.

3. Memperketat terjadinya jual beli Tanah Ulayat, dengan membuat Peraturan Kerapatan Adat Nagari yang mengatur bahwa jual beli tanah ulayat dibolehkan hanya dalam keadaan yang sangat terpaksa, dan bila itu terjadi di sarankan agar dicari pembeli yang lebih dekat terlebih dahulu. Pembeli yang sesuku, atau senagari, atau sebanuhampu, atau setidak-tidaknya masih orang minang. 
4. Menghidupkan kembali Lembaga Gadai sesuai ketentuan Adat Minangkabau, agar tanah Ulayat tidak terjual.

5. Memberikan penyuluhan Hukum Adat terhadap para Niniak Mamak/Penghulu, Pengatuo Suku/kaum tentang peran dan fungsinya dalam pelestarian tanah ulayat.

\section{SIMPULAN}

1. Bahwa Tanah Adat (Ulayat) Saat ini keberadannya di Banuhampum masih dapat dipertahankan. Walaupun sudah jauh berkurang. Hal ini dapat dibuktikan bahwa sampai sekarang Persekutuan Hukum dalam Masyarakat Hukum Adat yaitu Nagari, Suku, Kaum, masih tetap hidup dan eksis, dan masing-masing Persekutuan Hukum itu masih mempunyai hak ulayat walaupun baik dari segi kuantitas dan kualitasnya sudah berkurang.

2. Bahwa Ninik mamak/Penghulu/Pangatuo

Suku/Kaum adalah orang yang sangat besar peranannya di tengah-tengah kaum/persekutuannya, karena ninik mamak mempunyai hak dan kewajiban untuk mengurus anak dan kemenakannya beserta hak ulayat persekutuannya, dan mempunhai kewajiban untuk melestarikan hak ulayatnya.

3. Bahwa Hak Ulayat harus dipertahankan keberadaannya, karena hak ulayat merupakan identitas dari persekutuan dan hak ulayat bukan hak milik, maka hak ulayat dilarang untuk dialihkan atau dijual.

\section{DAFTAR PUSTAKA}

Amran, A. (2017). Penyelesaian sengketa tanah ulayat melalui lembaga adat di minangkabau sumatera barat. Jurnal hukum acara perdata adhaper, 3(2), 175-189.

Andiki, F., Prabandari, A. P., Studi, P., Kenotariatan, M., Hukum, F., \& Diponegoro, U. (2019). Peralihan Hak Tanah Ulayat Di Kabupaten Dharmasraya. Notarius, 12(2), 856865.

https://doi.org/10.14710/nts.v12i2.2 9130

Buan, R. (2017). Kedudukan Hak Ulayat Dalam Status Kawasan Lindung Di Sumatera Barat. Bina Hukum Lingkungan, $\quad 1(2), \quad$ 249-263. https://doi.org/10.24970/jbhl.v1n2.1 9

Ismail, I. (2010). Kedudukan dan Pengakuan Hak Ulayat dalam Sistem Hukum Agraria Nasional. Kanun: Jurnal Ilmu Hukum, 12(1), 49-66.

https://doi.org/10.24815/kanun.v12i 1.6287

Rifana, R. (2016). Peran Ninik Mamak Dalam Pemanfaatan Tanah Ulayat Di Kenagarian Lipat Kain Selatan. JOM Fakultas Hukum, 3(2), 1-15. https://doi.org/10.1017/CBO978110 7415324.004

Yunimar. (2017). Pensertipikatan Tanah Wakaf Yang Berasal Dari Tanah Ulayat Di Minangkabau Dalam Rangka Mewujudkan Kepastian 
Eviandi Ibrahim: Peranan Penghulu Terhadap Hak Ulayat Di Minangkabau

Hukum. Jurnal Normative, 5(1), 111.

Soeroso Wingjodipoero, (1982). Pengantar dan Asas-Asas Hukum Adat, Gunung Agung, Jakarta.

Dharmayuda, I. M. S. (2009). Status Dan Fungsi Tanah Adat Bali Setelah Berlakunya UUPA. Jakarta: CV Kayumas Agung

Edison; Nasrun DT.Marajo Sungut. (2010). Tambo Minangkabau (Budaya Dan Hukum Adat
Minangkabau. Bukit Tinggi: Kristal Multi Media.

Sukirno. (2018). Politik Hukum Pengakuan Hak Ulyat. Jakarta: Prenadamedia Group. Sutedi,

Nurmi Taswir, (2000). Hukum Agraria Nasional Indonesia, Unand Press, Padang.

Sayuti Thalib, (1985). Hubungan Tanah Adat dengan Hukum Agraria di Minangkabau, Bina Aksara, Jakarta. 